\title{
Near absent carrying angles: a clinical clue to underlying SHOX overdosage
}

\author{
Partha Pratim Chakraborty, Abhijit Mishra, Kalimujjaman Molla, Ratan Halder
}

Department of Medicine, Midnapore Medical College \& Hospital, Midnapore, West Bengal, India

\section{Correspondence to} Dr Partha Pratim Chakraborty, docparthapc@yahoo.co.in

Accepted 4 March 2019

\section{DESCRIPTION}

A 17-year-old right-handed boy with childhood onset seizure disorder presented to us with new onset diabetes mellitus. Clinical examination revealed tall stature (height: $181.2 \mathrm{~cm}$, mid-parental height: $166.4 \mathrm{~cm})$, normal body mass index $(20.1 \mathrm{~kg} /$ $\left.\mathrm{m}^{2}\right)$, normal waist circumference $(83.5 \mathrm{~cm})$ without acanthosis. The upper segment $(85.2 \mathrm{~cm})$ :lower segment $(96 \mathrm{~cm})$ ratio was 0.89 and the difference between arm span $(185.3 \mathrm{~cm})$ and height was $4.1 \mathrm{~cm}$. He had normal stretched penile length, small firm testes (left: $4 \mathrm{~mL}$, right: $3 \mathrm{~mL}$ ), Tanner stage 3 pubic hairs without gynaecomastia. He appeared to have no carrying angles, subsequently goniometry revealed grossly reduced carrying angles (right: $1^{\circ}$, left: $2^{\circ}$ )(figures 1 and 2 ). The relevant investigations have been summarised in table 1 .

Psychological testing with Binet Kamat Intelligence Test and The Vineland Social Maturity Scale revealed mild intellectual disability (intelligent quotient: 63) with 50\% intellectual impairment along with deficit in social adaptive functioning. G-banded karyotype from peripheral blood leucocytes documented 48, XXYY pattern(figure 3).

Carrying angle, the acute angle between the median axes of arm and a fully extended and supinated forearm is typically greater in females

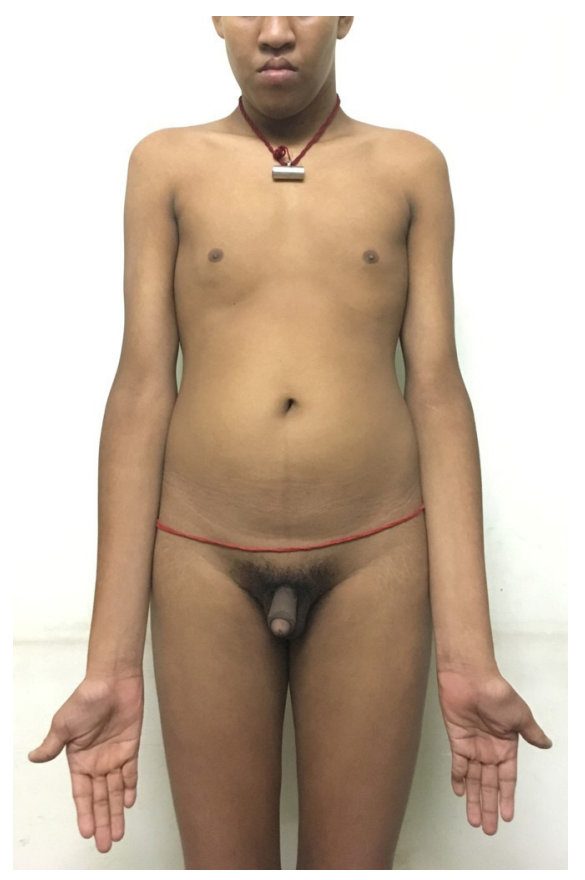

Figure 1 Clinical photograph showing absent carrying angles, normal penile length and Tanner stage 3 pubic hairs.
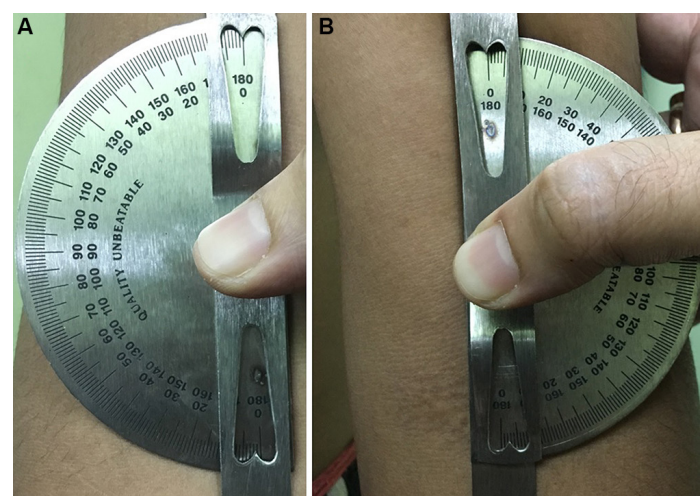

Figure 2 Measurement of carrying angles with a goniometer. The angle measured $1^{\circ}$ in right elbow $(A)$ and $2^{\circ}$ in left elbow (B).

compared with males. The relatively higher angle in females may be explained teleologically to accommodate the wider gynaecoid pelvis. This sexual dimorphism though not universal in prepubertal children, usually increases in girls post puberty; hence, carrying angle may be considered as a secondary sex characteristic of the females. The underlying reason(s), however, is unexplained and a number of postulations have been put forward. Height and forearm length have been found to be inversely related with carrying angle and females by virtue of their shorter height and forearm length have greater carrying angle. Some studies noticed no real sex differences and concluded that such apparent differences may be explained by increased joint laxity in females, permitting a greater degree

\begin{tabular}{|c|c|c|}
\hline Parameters & Patient's value & Reference range \\
\hline Fasting plasma glucose & 245 & $<100 \mathrm{mg} / \mathrm{dL}$ \\
\hline $\begin{array}{l}2 \text { hour postmeal plasma } \\
\text { glucose }\end{array}$ & 389 & $<140 \mathrm{mg} / \mathrm{dL}$ \\
\hline $\begin{array}{l}\text { Glycated haemoglobin } \\
\text { (HbA1c) }\end{array}$ & 10.6 & $<5.6 \%$ \\
\hline Triglyceride & 347 & $<150 \mathrm{mg} / \mathrm{dL}$ \\
\hline $\begin{array}{l}\text { High density lipoprotein } \\
\text { cholesterol }\end{array}$ & 21 & $>40 \mathrm{mg} / \mathrm{dL}$ \\
\hline Testosterone (09:00) & 132.9 & $295-545 \mathrm{ng} / \mathrm{dL}$ \\
\hline $\begin{array}{l}\text { Leutinising hormone } \\
\text { (pooled) }\end{array}$ & 19.63 & $1.5-9.3 \mathrm{mIU} / \mathrm{mL}$ \\
\hline $\begin{array}{l}\text { Follicle stimulating hormone } \\
\text { (pooled) }\end{array}$ & 29.9 & $1.4-18.1 \mathrm{mlU} / \mathrm{mL}$ \\
\hline $\begin{array}{l}\text { Ultrasonography of } \\
\text { abdomen }\end{array}$ & Fatty liver & \\
\hline Seminogram & Azoospermia & \\
\hline
\end{tabular}




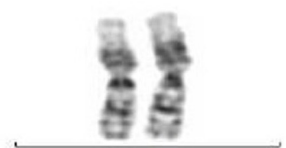

1

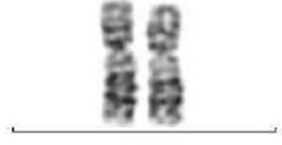

2

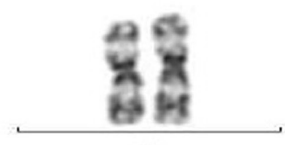

3

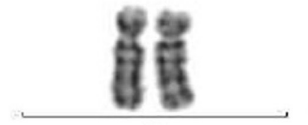

4

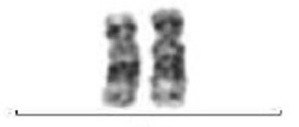

5

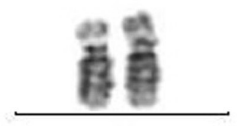

6

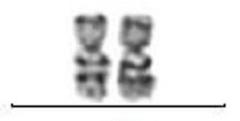

7

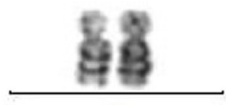

8

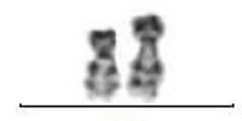

9

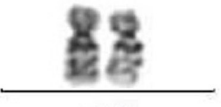

10

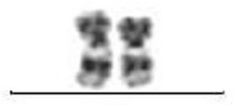

11

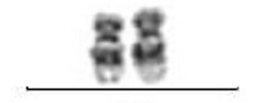

12

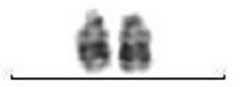

13

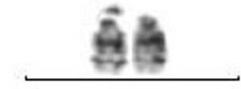

14

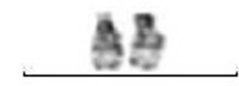

15

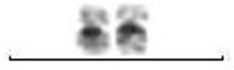

16

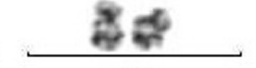

17
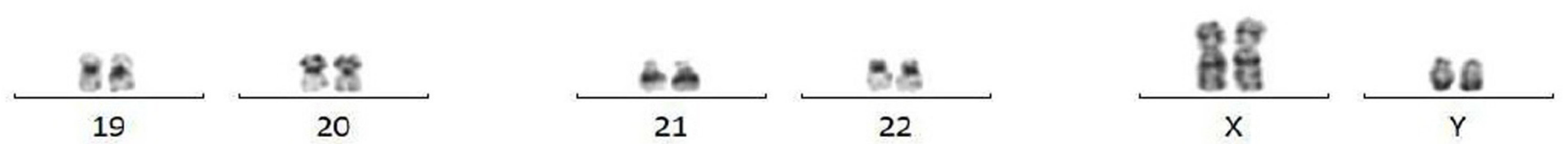

Figure 3 48, XXYY pattern in G-banded karyotype.

of extension. The carrying angle may be asymmetric as some studies have noticed greater carrying angle in dominant arm, while others came up with the reverse finding. The observed mean carrying angle in males varies in different studies and values ranging from $4.55^{\circ}$ to $19.4^{\circ}$ have been reported. Short stature homeobox-containing gene (SHOX) is also believed to play a role in the formation of carrying angle. SHOX resides in the pseudoautosomal region 1, situated in short arms of both the $\mathrm{X}$ and $\mathrm{Y}$ chromosomes (Xp22.3 and Yp11.3), escapes X inactivation and encodes a transcription factor exclusively expressed in the developing limbs and pharyngeal arch of the developing embryo. Increased carrying angle or cubitus valgus is seen in about $70 \%-85 \%$ cases of Leri-Weill dyschondrosteosis and Turner's syndrome, conditions characterised by SHOX deletions/ mutations and SHOX haploinsufficiency respectively. ${ }^{1}$

Cubitus varus is a condition when the carrying angle is decreased and complete loss of angulation is called cubitus rectus. Excess SHOX is expected to be associated with cubitus varus as encountered in conditions like 49, XXXXY, 48, XXYY and 48,XXXY syndromes. ${ }^{2}$ Radioulnar synostosis leading to limited supination/pronation is another elbow abnormality associated with 48,XXYY syndrome, which however was absent in this boy.

The above listed conditions mimic classical 47, XXY Klinefelter syndrome (KS) in many aspects and principles of management also do not differ much. An association between KS and type 2 diabetes has long been recognised due to increased adiposity secondary to hypogonadism. Similarly, boys with 48, XXYY karyotype are also vulnerable to metabolic syndrome and type 2 diabetes. Increased propensity for autoimmunity is also associated with increased risk of type 1 diabetes in both these conditions as well. Fertility can be achieved in some cases of KS if viable sperms are able to be retrieved. ${ }^{3}$ Unfortunately however, a severe delay in diagnosis, underdiagnosis or nondiagnosis is quite common in KS. Testosterone supplementation in KS needs to be initiated at the beginning of puberty, as follicle stimulating hormone and leutinising hormone start to rise, to secure sufficient increase in bone mineral density (BMD) and muscle bulk to prevent subsequent osteoporosis. So, it suffices to state that early diagnosis of such related syndromes is of utmost

\section{Learning points}

48, XXYY syndrome with an incidence between one in 17000 and 50000 live births shares many features with classical 47 , XXY Klinefelter syndrome (incidence one in 1000 live births) like tall stature, small firm testes and hypergonadotrophic hypogonadism. However, facial dysmorphism, skeletal abnormalities like cubitus rectus/varus and more pronounced cognitive, behavioural and intellectual disabilities are important distinctive features.

- Cubitus rectus or cubitus varus is a skeletal marker of short stature homeobox-containing gene overdosage and an important clinical clue to the underlying diagnosis particularly in peri-pubertal individuals with no/minimal hypogonadal symptoms.

- Early diagnosis of syndromes such as $48, X X Y Y$ is important to help address the learning and behavioural difficulties, to ensure appropriate testosterone and medical management and to guide discussions of current research related to possible fertility interventions. 
importance and the role of vigilant clinical examination can not be overemphasised.

Contributors PPC, AM, KM and RH were involved in diagnosis, work-up and management of the patient. PPC did the literature search and wrote the manuscript.

Funding The authors have not declared a specific grant for this research from any funding agency in the public, commercial or not-for-profit sectors.

Competing interests None declared.

Patient consent for publication Not required.
Provenance and peer review Not commissioned; externally peer reviewed.

\section{REFERENCES}

1 Ross JL, Scott C, Marttila P, et al. Phenotypes Associated with SHOX Deficiency. J Clin Endocrinol Metab 2001;86:5674-80.

2 Tartaglia N, Ayari N, Howell S, et al. 48, XXYY, 48, XXXY and 49,XXXXY syndromes: not just variants of Klinefelter syndrome. Acta Paediatr 2011;100:851-60.

3 Groth KA, Skakkebæk A, Høst C, et al. Clinical review: Klinefelter syndrome-a clinical update. J Clin Endocrinol Metab 2013;98:20-30.

Copyright 2019 BMJ Publishing Group. All rights reserved. For permission to reuse any of this content visit

https://www.bmj.com/company/products-services/rights-and-licensing/permissions/

BMJ Case Report Fellows may re-use this article for personal use and teaching without any further permission.

Become a Fellow of BMJ Case Reports today and you can:

- Submit as many cases as you like

- Enjoy fast sympathetic peer review and rapid publication of accepted articles

- Access all the published articles

Re-use any of the published material for personal use and teaching without further permission

For information on Institutional Fellowships contact consortiasales@bmjgroup.com

Visit casereports.bmj.com for more articles like this and to become a Fellow 